\title{
Pemetaan Proses dalam Pemodelan Proses Bisnis
}

\author{
Ary Carni Selis Diyah \\ Fakultas Ilmu Komputer, Progam Studi Sistem Informasi \\ Institut Informatika dan Bisnis Darmajaya \\ Email: arycarni.1311050165@mail.darmajaya.ac.id
}

\begin{abstract}
Abstrak: Judul jurnal ini adalah "Pemetaan Proses dalam Pemodelan Proses Bisnis". Penulisan jurnal ini diharapkan dapat menjawab rumusan masalah mengenai pemetaan proses dalam pemodelan proses bisnis. Dari rumusan masalah tersebut, terdapat tujuannya yakni: Untuk mengetahui seberapa besar pengaruh pemetaan proses bisnis terhadap kinerja perusahaan. Metode penulisan yang digunakan dalam jurnal ini adalah metode kepustakaan. Setelah pemaparan teori yang berhubungan dengan permasalahan, maka dapat disimpulkan bahwa pemetaan proses menggambarkan tata letak aktifitas yang terjadi dalam sebuah perusahaan. Sehingga, pemilihan tools pemetaan yang sesuai dapat memberi dampak baik pada perusahaan dan juga dapat memaksimalkan keuntungan tentunya.
\end{abstract}

Kata kunci: pemetaan, proses, pemodelan proses bisnis, visualisasi, tools.

Dalam beberapa tahun ini banyak perusahaan start-up berdiri dan berkembang cukup pesat, khususnya di Indonesia. Keadaan ini memunculkan banyak aktifitas-aktifitas yang terjadi dalam suatu perusahaan terutama terjadinya proses bisnis pada operasional perusahaan. Namun, pada faktanya terdapat beberapa perusahaan ternyata belum dapat memaksimalkan proses-proses yang ada. Dalam hal ini, dibutuhkan pemetaan permodelan proses bisnis yang baik guna menghindari kesalahan dan meningkatkan efektivitas kinerja perusahaan. Berdasarkan hal tersebut, terdapat rumusan masalahnya yakni: Bagaimana proses pemetaan bisnis dilakukan didalam perusahaan dengan tujuan untuk mengetahui seberapa besar pengaruh pemetaan proses bisnis terhadap kinerja perusahaan.

\section{PEMBAHASAN}

\subsection{Sekilas tentang Pemetaan Proses}

Pemetaan proses adalah visualisasi dari rangkaian seluruh aktivitas dari suatu organisasi, yang mendemonstrasikan bagaimana pekerjaan di dalam organisasi tersebut dilakukan, sehingga menjadikan pekerjaan tergambar dengan jelas/eksplisit (Robert Damelio, 1996).

Dengan pemetaan proses sebuah organisasi memiliki dokumentasi mengenai pekerjaan yang dilakukan, sehingga memungkinkan untuk menganalisa pekerjaan yang telah dilakukan bagi peningkatan kepuasan pelanggan melalui identifikasi terhadap pengurangan waktu proses, mengurangi produk defect, mereduksi biaya, mereduksi tahapan proses yang tidak menghasilkan nilai tambah, meningkatkan produktivitas, dan memudahkan pengukuran performansi. Penggunaan peta proses bisnis lainnya adalah:

- Sebagai alat evaluasi atau alternatif untuk mengorganisasikan sumber daya manusia.

- Untuk mengidentifikasikan peluang peningkatan.

- Untuk melakukan evaluasi dan memperketat pengukuran kinerja. 
Proses secara sederhana dapat didefinisikan sebagai rangkaian aktivitas yang merubah input menjadi output yang bernilai tambah. Berikut gambar menunjukkan interaksi antar proses yang terjadi dalam satu organisasi dapat dilihat pada Gambar 1.

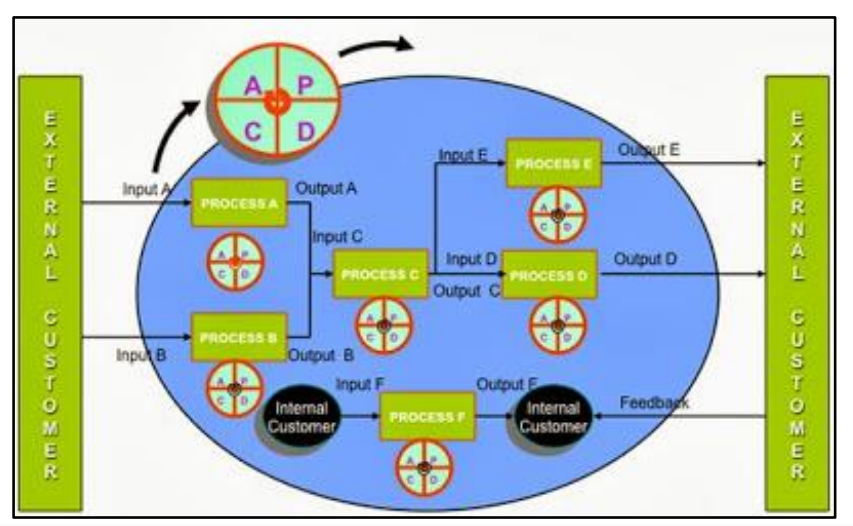

Gambar 1. Interaksi Proses yang Membentuk Proses Bisnis

Untuk dapat membangun pemetaan proses yang representatif, maka diperlukan pengetahuan dan pemahaman mengenai proses yang akan dipetakan. Berikut ini merupakan hierarki proses, yang akan menjelaskan mengenai proses dan komponen-komponen yang membangunnya (David Hoyle, 1998).

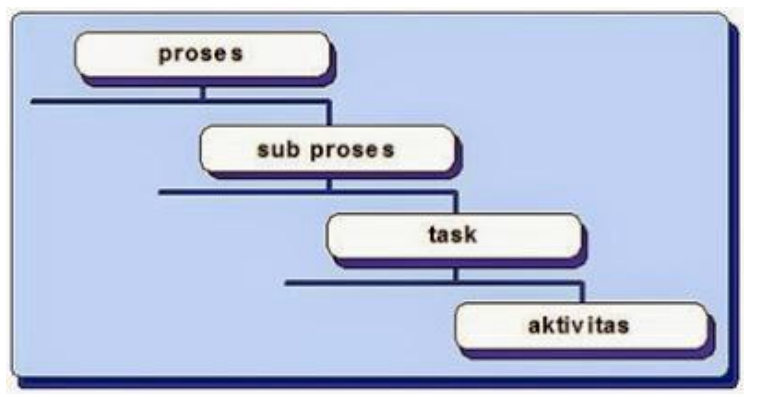

Gambar 2. Hierarki Proses

Keterangan:

- Proses merupakan rangkaian aktivitas logis yang saling berhubungan dan berkesinambungan dalam mengolah keluaran dari supplier, memberi nilai tambah, dan menjadikannya keluaran bagi customer.

- Sub proses adalah bagian dari proses yang memiliki tujuan spesifik dalam mendukung major process. Sub proses merupakan bagian dari proses, bila major process terlalu kompleks.

- Task merupakan gabungan aktivitas yang ditujukan untuk tujuan minor dalam sebuah organisasi. Task adalah pekerjaan di dalam work process yang harus dilakukan.

- Aktivitas merupakan bagian terkecil dari pekerjaan yang harus dilakukan untuk menyelesaikan suatu task.

Dalam pemetaan proses dapat kita mulai dengan menggambarkan seluruh aktifitas yang terjadi dalam suatu organisasi menjadi kelompok besar aktivitas yang kita sebut sebagai peta 
proses bisnis. Dari peta proses bisnis ini kemudian dapat didetailkan menjadi sub peta proses bisnis dan kemudian menjadi SOP dan intruksi kerja .

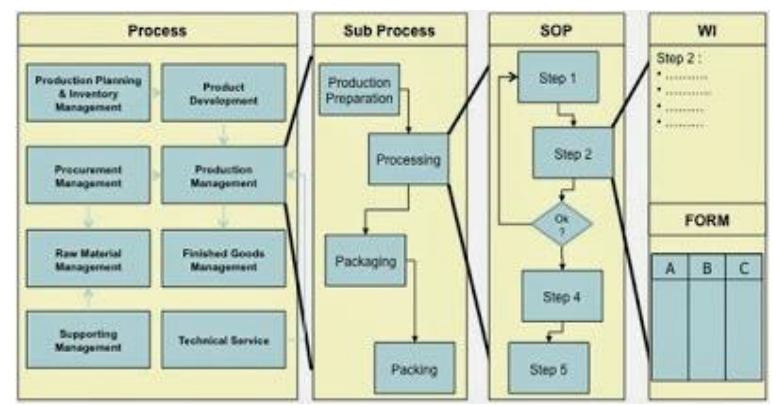

Gambar 3. Sistematika Peta Proses Bisnis

Perlu diingat dokumen SOP adalah dokumen yang mengatur tata cara bagaimana proses diselesaikan dengan tuntas dalam memberikan nilai tambah terhadap outputnya. Dengan demikian dokumen SOP berisikan norma dan menjelaskan yang menjelaskan bagaimana, siapa, dan hasil apa yang diwujudkan dalam bentuk-bentuk fungsi yang diperlukan lintas fungsi dalam organisasi.

Oleh karena itu sebelum menuliskan SOP, ada baiknya kita menggambarkan peta lintas fungsi fungsi ( lintas peta fungsional. Menyeberang fungsional peta merupakan peta yang menggambarkan Hubungan antar fungsi fungsi dengan urutan aktivitas hearts menyelesaikan Proses Tertentu. Untuk dapat memastikan siapa saja yang terlibat dalam satu proses perlu diidentifikasikan lebih dalam peta hubungan ( relationship map ).

Relationship Map adalah peta yang menghubungkan hubungan-pemasok (pelanggan pelanggan ) antar bagian dalam suatu organisasi, baik itu antar fungsi, departemen, atau divisi. Informasi yang didapat dari Relationship Map antara lain:

- Apa yang dihasilkan oleh organisasi terkait (produk dan layanan).

- Bagaimana alur pekerjaan yang melewati batasan fungsional (pekerjaan lintas fungsi).

- Hubungan pemasok - pelanggan baik internal maupun eksternal yang untuk menyediakan atau menerima produk dan layanan.

Secara keseluruhan, proses penyusunan yang dapat digunakan seperti gambar dibawah ini.

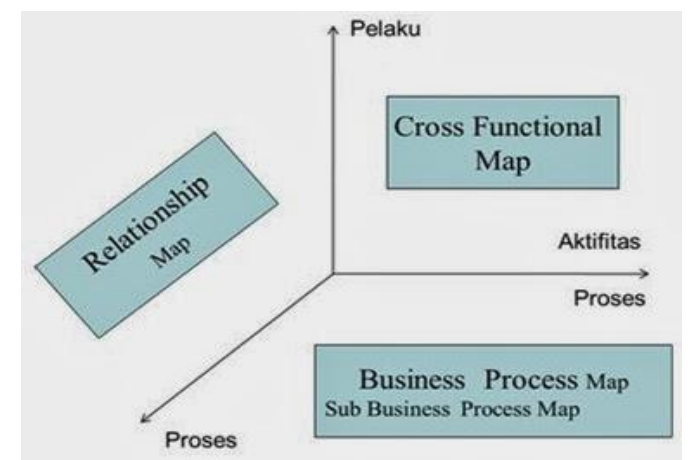

Gambar 4. Peta Proses yang Lengkap 
Keterangan:

- Peta Proses Bisnis - Sub Proses Bisnis Peta merupakan hubungan antara proses dengan proses.

- Hubungan Peta merupakan hubungan keterkaitan antara proses dengan pelaku.

- Cross Functional Map merupakan hubungan keterkaitan antara pelaku dengan aktifitas.

Dengan demikian, penyusunan pemetaan proses bisnis dimana hal-hal tersebut merupakan visualisasi dari organisasi, yang mendemonstrasikan bagaimana pekerjaan yang dilakukan, dalam konteks yang jelas (Robert Damelio, 1996). Dengan menggunakan sebuah organisasi yang memiliki pekerjaan yang dilakukan, memungkinkan untuk menganalisa pekerjaan yang telah dilakukan untuk meningkatkan kepuasan melalui proses, proses yang tidak dapat meningkatkan, dan meningkatkan kinerja. Penggunaan peta proses lain antara lain:

- Sebagai alat evaluasi atau alternatif untuk mengorganisasikan sumber daya manusia.

- Untuk mengidentifikasikan peluang peningkatan.

- Untuk melakukan evaluasi dan memperketat pengukuran kinerja.

\subsection{Tools Pemetaan Proses}

Seperti kebanyakan tool DFSS, pemetaan proses membutuhkan sebuah usaha tim crossfunctional dengan keterlibatan dari pemilik proses, anggota proses, customer, dan suppliers. Brainstorming, manual operasi, spesifikasi, pengalaman operator, dan jalannya/aliran proses adalah input yang sangat kritis untuk aktivitas pemetaan. Sebuah peta proses yang detail memberikan input untuk tools lain seperti FMEA, transfer function DOEs, studi kapabilitas, dan perencaaan pengendalian.

Peta proses dapat dibuat pada level yang berbeda, mengerucut atau melebar dari target proses dan menyampaikan jasa dibawah pertimbangan proyek DFSS. Untuk membuat peningkatan di sebagian besar proses, penting untuk mengerti cara aktual mengenai kerja proses. Dalam konteks ini, mudah untuk memahami alasan aliran masalah dan kemudian menuju pada penyebab. Dalam pemetaan proses, simbol menunjukkan langkah proses, pengukuran, antrian, storage, transportasi (pergerakan), dan keputusan (Gambar 5).

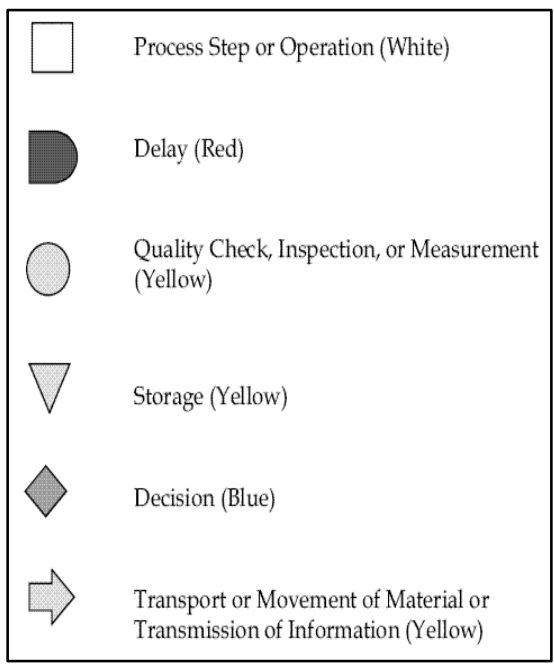

Gambar 5. Simbol standar pemetaan proses 
Ada tiga versi dari peta proses (Gambar 6). Mereka adalah "untuk apa ini didesain", yang biasanya sebuah clean flow (aliran bersih). Ada peta proses "as-is", dengan semua variasi yang terjadi karena variasi suppliers, customers, operator, dan kondisi. Versi terakhir adalah "apa yang kita inginkan", dengan hanya langkah-langkah value-added. Ini bersih, intuituf, dan bekerja benar setiap waktu.

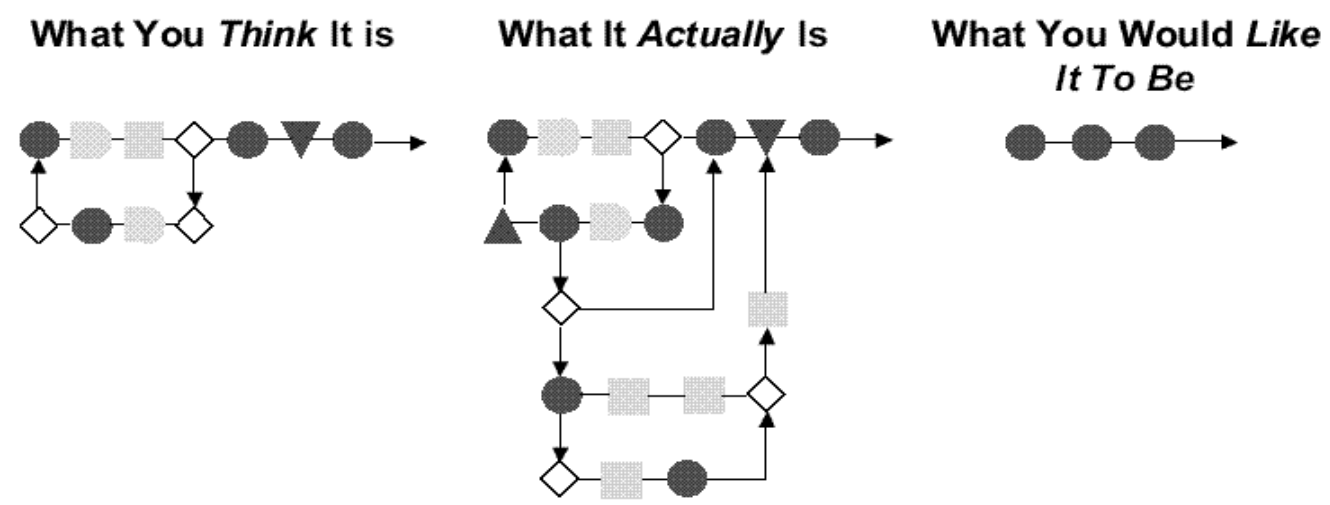

Gambar 6. Tiga Versi Peta Proses

Sebuah peta proses adalah sebuah gambar representasi yang menunjukkan semua langkah dalam proses. Sebagai langkah pertama, tim harus membiasakan dirinya dengan simbol pemetaan, kemudian melalui proses dengan menanyakan pertanyaan seperti: "Apa yang sebenarnya terjadi selanjutnya dalam proses?" "Apakah sebuah keputusan harus dibuat sebelum proses berikutnya?" atau "Apa persetujuan yang dibutuhkan sebelum bergerak ke tahap/tugas berikutnya?".

Tim kemudian menggambar proses menggunakan simbol dalam sebuah flip chart atau transparansi overhead. Setiap proses akan memiliki sebuah start dan sebuah end (oval). Semua proses akan memiliki tugas dan sebagian besar memiliki poin keputusan (diamonds). Dalam pelengkapan, tim harus menganalisa peta untuk setiap item yang termasuk langkah non-value-added, rework loop, duplikasi, dan waktu siklus. Sebuah peta proses level tinggi terlihat pada Gambar 7.

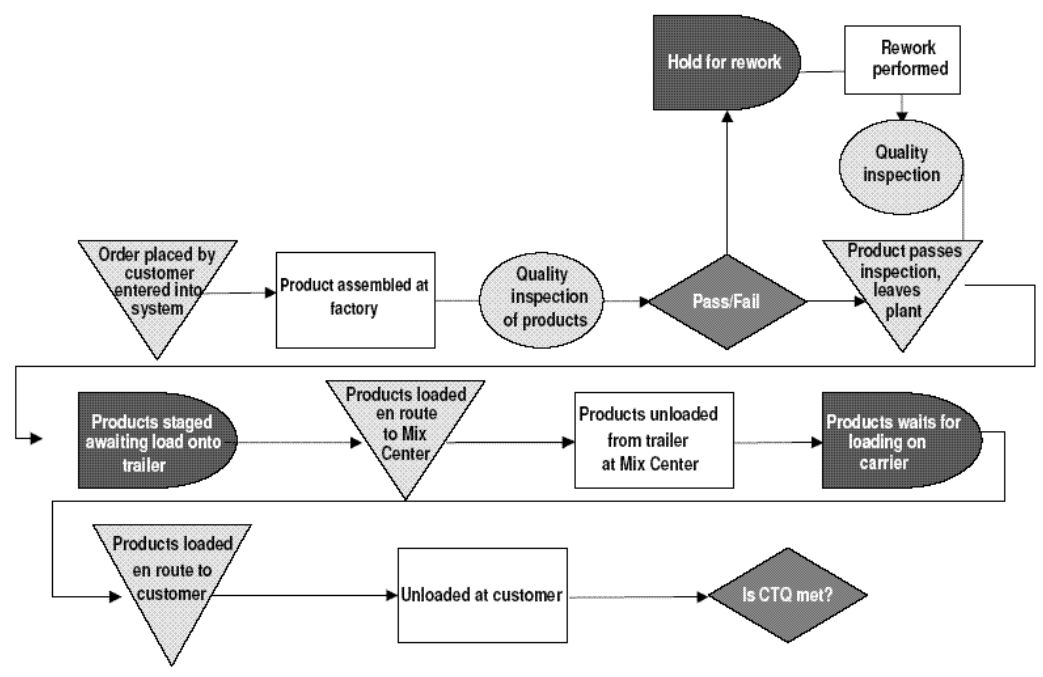

Gambar 7. Contoh Peta Proses Level Tinggi 
Sebuah peta proses harus mengidentifikasi semua langkah proses atau operasi termasuk pengukuran yang terlihat, inspeksi, rework loops, dan decision points. Selain itu, "swim lanes" sering digunakan ketika aliran informasi pemetaan untuk jasa tipe transaksional dan proses bisnis. Kami percaya bahwa swim lane sesuai untuk semua tipe proyek DFSS.

Swim lane memisahkan langkah dengan siapa mereka atau dimana mereka dilakukan dan membuat pandangan hand-offs. Peta disusun dalam sebuah tabel dimana kolomnya mengindikasikan "who" yang memiliki atau melakukan langkah proses (process owner), dan aliran proses yang mengubah "lanes" mengindikasikan hands-off. Hands-off point dimana terjadi kurang koordinasi dan komunikasi dapat menyebabkan masalah dalam proses. Sebuah contoh digambarkan pada Gambar 8.

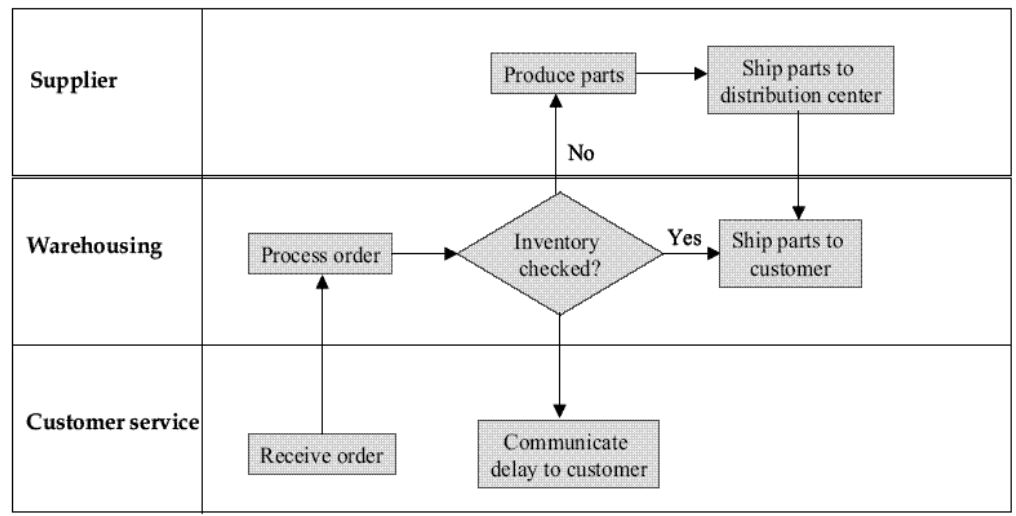

Gambar 8. Peta Proses High Level Swim Lanes

Pemetaan proses adalah sebuah metodologi yang disusun melalui langkah dan tindakan berikut:

\section{Langkah 1. Mendefinisikan proses}

Tujuan/lingkup proyek yang didefinisikan.Meninjau kembali tujuan untuk memilih dan membuat prioritas proses untuk dipetakan. Fokus pada waktu, input, fungsi, hand-offs, batasan wewenang dan tanggung jawab, dan output. Level yang sesuai untuk diskusi yang mendetail. Hubungan dengan analisis lain. Daftar langkah proses level tinggi. Dokumen aliran proses keseluruhan dalam batasan start dan stop.

\section{Langkah 2. Megumpulkan informasi}

Kebutuhan data. Menggunakan sampling dan teknik pengumpulan (fokus kelompok, wawancara, observasi). Sumber yang dibutuhkan dalam langkah pemetaan dan latihan pemetaan secara umum. Jadwal pelaksanaan proses berdasarkan shift, hari, dan minggu dimana pekerjaan khusus/unik terjadi. Kapan kita melakukan zoom dalam langkah proses pada peta? Aliran yang kontinu.Proses berhenti (ketika aliran terganggu atau terputus). Memiliki variabel input dan output proses (PIV, xs, dan POV, ys) diidentifikasi.

Ingat bahwa kita telah melakukan fungsi transfer yang menjelaskan secara lengkap apa yang terjadi/harus terjadi untuk memperkuat bahwa solusinya benar-benar optimal. Mempertimbangkan penggabungan dari multiple step. Menambahkan spesifikasi operasi. Jelas dalam terminologi dan nomenclature sehingga setiap orang berbicara bahasa yang sama. 
Menghindari bias, bahasa nonteknik. Tetap konsisten. Mengakumulasi daftar item "quickhits" dan mengembangkan rencana tindakan untuk penerapan.

\section{Langkah 3. Validasi dan verifikasi}

Pastikan penggunaan istilah yang umum dan nomenclature.Konsolidasi, pemenuhan, dan reconcile informasi.Merangkum penemuan-penemuan.Validasi informasi.Konfirmasi data kontroversial.

\section{Langkah 4. Membangun peta proses}

Antrian aktivitas dan langkah kerja berdasarkan langkah sebelumnya. Swim lane (bila diperlukan). Awal dan akhir proses.Langkah kerja yang ditetapkan untuk peserta. Pembagian waktu untuk setiap langkah kerja. Penaksiran awal dari perancanaan pengendalian. Memulai penaksiran awal setelah peta proses lengkap. Menambah teknik pengukuran. Mendefinisikan spesifikasi operasi. Menyatakan target. Mengetahui konteks pemetaan proses dalam proyek. Apakah pemetaan proses cocok dengan analisis sebelumnya? Mengadakan benchmarking. Performansi baseline/saat ini. Uraian dokumen.

\section{Langkah 5. Analisa dan penyusunan kesimpulan}

Mengidentifikasi karakteristik dari langkah proses. Mendefinisikan hipotesis mengenai bagaimana hubungan variabel input dan output dalam proses relatif terhadap mean dan variansi target. Merencanakan pekerjaan follow-up jika ada (misalnya sistem pengukuran baru, grafik SPC). Melihat perbaikan atau peluang redesain. Menerapkan skenario simulasi "if-then" untuk perubahan layout.

\section{Langkah 6. Mengkomunikasikan rekomendasi, penemuan, dan kesimpulan}

Membiasakan/memberikan presentasi kepada pendengar mengenai penerapan/ implikasi perubahan. Update spesifikasi, perencanaan pengendalian, prosedur, pelatihan, dan sebagainya.

Tujuan Pemetaan Proses, yakni:

1. Membantu dalam menggunakan model sederhana.

2. Membantu beberapa pihak yang tidak paham dengan tulisan.

3. Membantu menggambarkan sistem secara lengkap.

4. Mudah di pahami pihak terkait baik manajemen maupun user.

5. Sebagai media menyimpan informasi.

6. Membantu pekerjaan, DLL.

\section{SADT (Structure Analysis and Design Technique )}

Structure Analysis and Design Technique atau Analisis terstruktur dan teknik desain adalah rekayasa sistem dan metodologi rekayasa perangkat lunak untuk menggambarkan sistem sebagai hierarki fungsi atau metodologi pengembangan sistem terstruktur. SADT merupakan notasi diagram yang dirancang khusus untuk membantu orang menggambarkan dan memahami sistem. Ia menawarkan blok bangunan untuk mewakili 
entitas dan kegiatan, dan berbagai panah untuk menghubungkan kotak. Kotak dan panah ini memiliki semantik informal yang terkait.

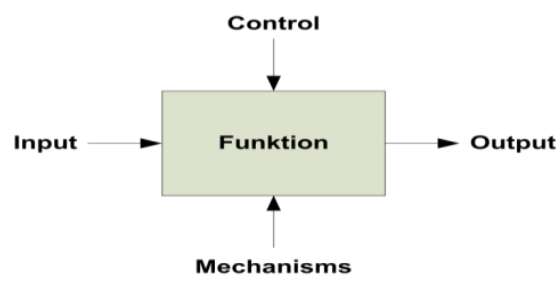

Gambar 9. Elemen dasar SADT

SADT dapat digunakan sebagai alat analisis fungsional dari proses yang diberikan, menggunakan tingkat rincian yang berturut-turut. Metode SADT tidak hanya memungkinkan seseorang untuk menentukan kebutuhan pengguna untuk perkembangan TI, yang sering digunakan dalam Sistem Informasi industri, tetapi juga untuk menjelaskan dan menyajikan proses dan prosedur produksi suatu kegiatan.

SADT menggunakan dua jenis diagram: model aktivitas dan model data yaitu:

1. Benda (obyek, dokumen atau data).

2. Kejadian (kegiatan yang dilakukan oleh orang, mesin atau perangkat lunak).

Dua Tipe Diagram yg digunakan didalam paket SADT :

1. Diagram kegiatan (activity diagram) yang disebut dengan actigrams.

2. Diagram data (data diagram) yang disebut dengan datagrams.

\section{Prinsip Pengembangan Sistem}

SADT sebagai metodologi pengembangan sistem terstruktur juga menganut konsep DEKOMPOSISI (menggambarkan sistem secara utuh terlebih dahulu (whole sistem) sebagai tingkat tertinggi (top level) dan memecah menjadi yg lebih rinci.

\section{Actigrams}

Pada Actigrams (diagram kegiatan pada SADT) simbol terdapat 2 simbol yaitu:

KOTAK Menunjukkan kegiatannya PANAH Menunjukkan :

- Data yg digunakan oleh kegiatan yg bersangkutan (input data).

- Data yg dihasilkan oleh kegiatan yg bersangkutan (output data).

Berikut contoh gambar:

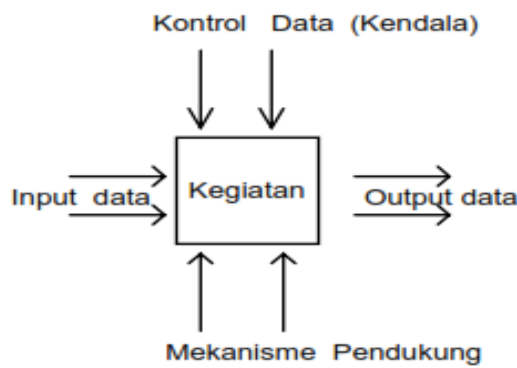

Gambar 10. Contoh Proses Input Output Proses Bisnis 


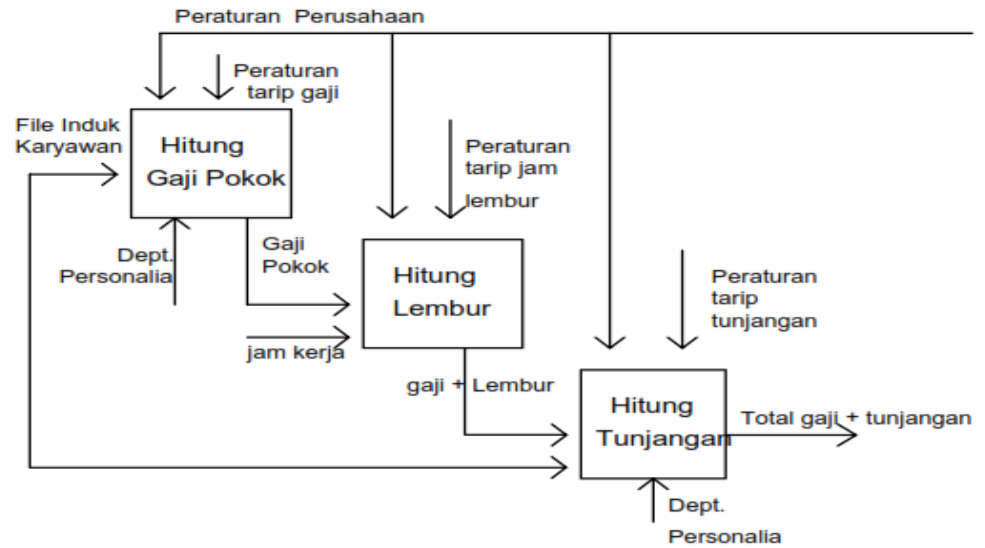

Gambar 11. Contoh Proses Input Output Proses Penggajian Karyawan

\section{Kelebihan SADT}

1. SADT mudah dipelajari.

2. Merupakan alat yg baik untuk digunakan sebagai komunikasi antara analis sistem dengan pemakai sistem selama proses pengembangan sistem.

3. Hasil daro desain sistem akan didapatkan dokumentasi yg baik.

4. Dengan spesifikasi desain yg sama kebanyakan perancang sistem akan menghasilkan solusi yang hampir mirip.

\section{Kekurangan SADT}

1. Membutuhkan waktu \& personil yang lebih banyak untuk membuatnya.

2. Metodologi ini hanya bagus untuk tahap analisis dan desain secara umum.

3. Proses didalam modul tidak digambarkan di SADT.

4. Aplikasi dari metodologi ini tidak membutuhkan tingkat keahlian yg tertentu \& pengalaman dari analis sistem.

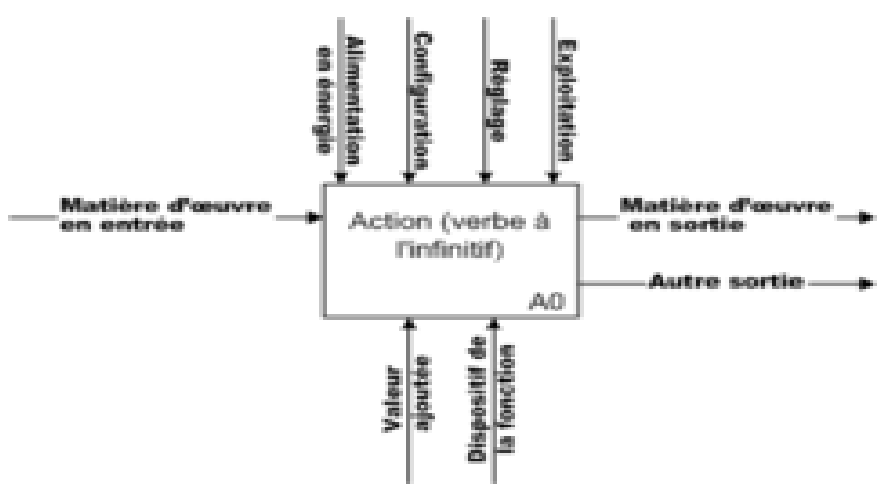

Gambar 12. Contoh lain SADT

SADT menggunakan dua jenis diagram: model aktivitas dan model data. Ia menggunakan panah untuk membangun diagram ini. Representasi SADT adalah sebagai berikut:

- Kotak utama tempat nama proses atau tindakan ditentukan.

- Di sisi kiri kotak ini, panah masuk: masukan dari tindakan.

- Di bagian atas, panah yang masuk: data yang diperlukan untuk tindakan. 
- Di bagian bawah kotak, panah yang masuk: berarti digunakan untuk tindakan.

- Di sisi kanan kotak, panah keluar: output dari aksi.

Semantik panah untuk kegiatan:

- Masukan masuk dari kiri dan mewakili data atau barang habis pakai yang dibutuhkan oleh aktivitas.

- Output keluar ke kanan dan mewakili data atau produk yang dihasilkan oleh aktivitas.

- Kontrol masuk dari atas dan mewakili perintah atau ketentuan yang memengaruhi pelaksanaan suatu aktivitas tetapi tidak dikonsumsi.

- Mekanisme mengidentifikasi sarana, komponen atau alat yang digunakan untuk menyelesaikan aktivitas. Mewakili alokasi kegiatan.

Semantik panah untuk data:

- Input adalah kegiatan yang menghasilkan data.

- Output mengkonsumsi data.

- Kontrol mempengaruhi keadaan internal data.

SADT digunakan sebagai notasi diagram dalam desain konseptual rekayasa perangkat lunak dan rekayasa sistem untuk aplikasi sketsa, untuk analisis struktur yang lebih rinci, untuk definisi persyaratan, dan desain terstruktur.

\section{Pengertian Swimlane}

Diterjemahkan dari bahasa Inggris Jalur berenang digunakan dalam diagram alur proses, atau bagan alur, yang secara visual membedakan pembagian kerja dan tanggung jawab untuk subproses proses bisnis. Jalur berenang dapat disusun secara horisontal atau vertikal Swimlane process diagram adalah sebuah diagram flow proses yang menggambarkan interaksi dari beberapa bagian yang berbeda yang terlibat dalam sebuah lini proses bisnis.

Diagram ini menggunakan format jalur hubungan (swimlane), adapun menggambarkannya dilakukan dengan cara menampilkan stakeholder pada baris diagram serta kerangka waktu pada kolom diagram; dan kemudian aktivitasnya ditampilkan menggunakan simbol flowchart. Swim Lane Process Diagram adalah diagram yang menggambarkan aktivitas dari setiap stakeholder yang terlibat di dalam kegiatan bisnis perusahaan; diagram ini merepresentasikan flow proses yang menggambarkan interaksi dari beberapa bagian yang berbeda dan bagaimana perkembangan proses melalui beberapa phase yang berbeda.

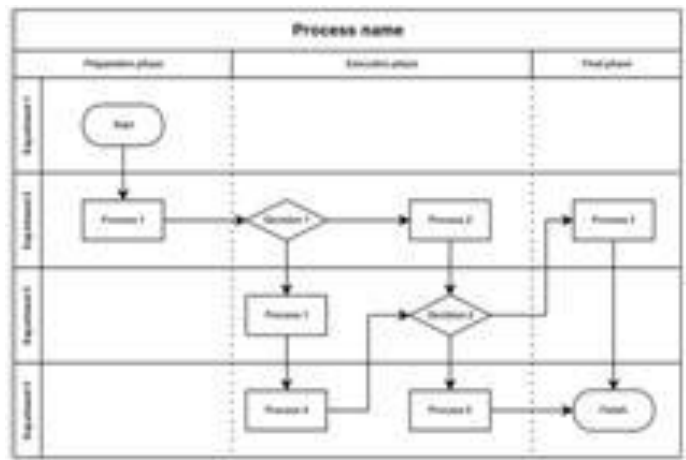

Gambar 13. Swimlane Diagram 
Swim lane diagram sering disebut juga "Deployment Process Map" atau "Cross Functional Flowchart" adalah sebuah diagram yang merepresentasikan flow proses yang menggambarkan interaksi dari beberapa bagian yang berbeda dan bagaimana perkembangan proses melelui beberapa phase yang berbeda. Diagram Stakeholder Activity menunjukkan stakeholder (orang yang secara pribadi berminat dalam enterprise) yang terlibat dalam proses lini bisnis, dan ketepatan dari interaksi.

Berikut merupakan contoh swim lane process diagram pada payroll prosess dimana terdiri dari beberapa stakeholder yang terlibat, yaitu: human resources, employee, manager, payroll, dan payroll vendor.

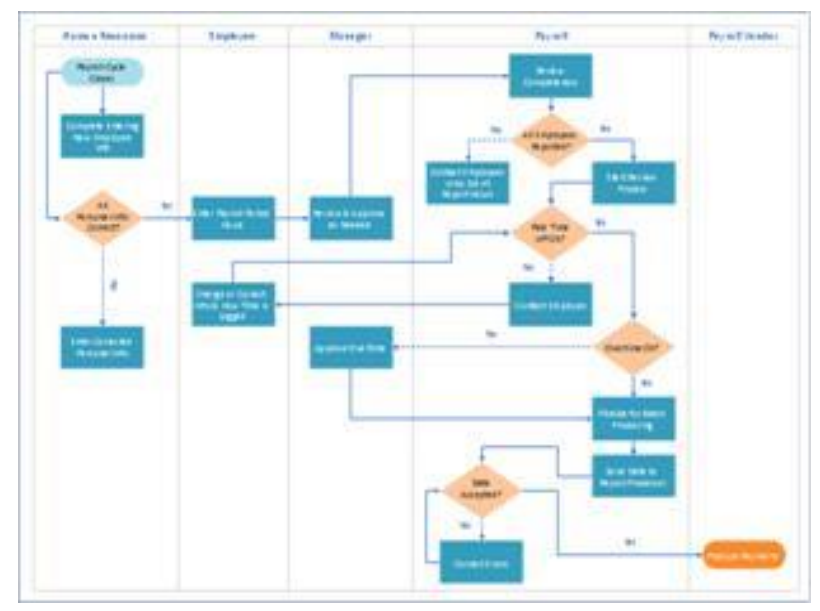

Gambar 14. Contoh Swimlane Process Diagram pada Payroll Process

\section{Level pada Swimlane :}

- Level 1 Handoff-level, Handoff level menggambarakn aktivitas utama . aktivitas yang menjadi aktifitas utama suatu proses bisnis. setiap perpindahan proses / aktifitas harus juga berpindah aktor dan sebida mungkin tidak menggunakan desision.

- Level 2 Milestone-level, Milestone menjelaskan apa aktifitas selanjutnya bisa disebut juga aktifitas pelengkap pada satu aktor.Menggambarkan aspek keputusan atau pilihan yang dapat memperngarui alur aktifitas. menggambarkan mekanisme Handoff level. Menggambarkan pengulangan (looping). Menggambarkan pencapaian milestone (aktifitas yang ada diantara aktifitas utama).

- Level 3 Task-level, Menggambarkan bagaimana suatu aktifitas dilakukan (Dekomposisi) / menjabarkan kembali aktifitas. Memperlihatkan perfomansi dari proses bisnis.

\section{Critical Success Factors}

CSF dapat didefinisikan sebagai wilyah tertentu atau hal-hal yang penting bagi keberhasilan suatu organisasi. Untuk memastikan kinerja organisasi, perhatian khusus atau concern harus diberikan pada wilayah yang akan menentukan keberhasilan organisasi, baik sekarang dan masa datang (Boynton, A.C., and Zmud, R.W. 1984. "An Assessment of Critical Success Factors," Sloan Management Review (25:4), pp. 17-27). 
CSF sangat penting bagi pencapaian sasaran dan ambisi perusahaan. Misalnya CSF yang berkaitan dengan uang- peningkatan arus kas dan keuntungan. CSF yang berkaitan dengan pelanggan - peningkatan jumlah dan tiadanya keluhan. CSF dapat juga berupa pengembangan yang berkaitan dengan apa yang harus dilakukan untuk memperbaiki bisnis? Bagaimana meningkatkan produktivitas? Teknologi baru yang harus dikembangkan untuk memenuhi permintaan pasar? Atau teknologi baru apa yang harus diadopsi? Hal-hal seperti ini menentukan sukses dan karenanya mereka disebut CSF.

\section{Key Performance Indicator}

memainkan peran penting pada keberhasilan organisasi sekarang dan mendatang. (Parmenter D, 2007, Key Performance Indicators (KPI): Developing, Implementing and Using Winning KPIs, Wiley, John \& Sons, Incorporated, Pub. Date: January 2007, pp.3).

Sebuah KPI adalah suatu instrumen untuk mengkuantitatifkan atau mengkualitatifkan sasaran taktis suatu institusi tergantung pada prioritas yang diinginkan. Indikator sesungguhnya adalah cara untuk menilai atau mengakses kinerja (access the performance) atau mengukur sukses perusahaan tetapi tidak memperlihatkan bagaimana memperbaiki. Sesuai namanya 'indicators' yang hanya berfungsi mengindikasikan. Sebuah KPI digunakan untuk mengukur kinerja, tetapi CSF membantu kita menemukan wilayah yang harus diperbaiki sehingga sukses dapat diraih.

\section{Perbedaan antara KPI dan CSF}

Secara lebih rinci, perbedaan antara KPI dan CSF diuraikan sebagai berikut:

CSF merupakan akibat dari keberhasilan Anda atau apa yang diperlukan agar sukses, sebaliknya KPI adalah dampak dari tindakan (action) Anda, yang mengindikasikan tentang apa yang sedang Anda lakukan dan bukan yang seharusnya dilakukan.

CSF dapat didefinisikan sebagai 'apa yang seharusnya dilakukan untuk mencapai sukses?' dan KPI didefinisikan apakah kita sukses?' CSFs bersifat umum, seperti keuntungan, kepemimpinan, penilaianan yang baik (mature assessment), distribusi tanggungjawab secara benar dan peran manusia, sistematisasi setiap proses, sasaran definitif atau rencana perbaikan yang diimplementasikan secara benar, dsbnya.

Sebaliknya KPI tidak begitu, tetapi mereka ditentukan mengikuti prioritas sesuai dengan jenis organisasi. Kalau untuk perusahaan yang mengejar laba maka indikator soal keuangan menjadi perhatian utama, sementara pada institusi pendidikan indikator lebih pada standar pendidikan atau hal-hal lain yang terkait dengan mahasiswa.

\section{MPI (Message Passing Interface)}

Pengertian MPI (Message Passing Interface) adalah spesifikasi API (Application Programming Interface) yang memungkinkan terjadinya komunikasi antar komputer pada network dalam usaha untuk menyelesaikan suatu tugas. Paradigma Message - Passing dengan implementasi MPI memberikan suatu pendekatan yang unik dalam membangun suatu software dalam domain fungsi tertentu, yang dalam hal ini pada lingkungan sistem 
terdistribusi, sehingga memberikan kemampuan pada produk software yang dibangun diatas middleware tersebut untuk dapat mengeksploitasi kemampuan jaringan komputer dan komputasi secara paralel.

MPI adalah standar interface dari model message - passing yang didefenisikan oleh sebuah grup yang terdiri dari 60 orang yang berasal dari 40 organisasi baik vendor komersil maupun dari kalangan peneliti akademisi yang berada di Amerika Serikat dan Eropa. Dalam grup tersebut mereka mencoba merumuskan dan membuat sebuah "standard by consensus" untuk pustaka message - passing yang dapat digunakan dalam komputasi paralel. MPI menjadi standar defacto yang banyak digunakan dalam komunikasi proses pada model dari program paralel pada sistem memori terdistribusi, yang mana banyak diimplementasikan oleh pada super komputer dan computer cluster.

Implementasi MPI merupakan sebuah API yang dapat dipanggil dari beberapa bahasa pemrograman seperti Fortran, $\mathrm{C}$, ataupun $\mathrm{C}++$, dan bersifat portable. Terdapat dua versi standar yang pada saat ini populer digunakan, yaitu versi 1.2 (MPI-1) yang berfokus pada message passing dan memiliki static runtime enviroment, dan MPI-2.1 (MPI-2) yang memasukkan fitur - fitur baru seperti parallel I/O, dynamic process management, remote memory operation dsb.

\section{Tujuan MPI}

MPI merupakan sebuah protokol komunikasi yang sifatnya language-independent, portable dalam mensupport berbagai platform, dan memiliki spesifikasi semantic yang mengatur bagaimana perilaku setiap impelementasinya. MPI mendukukung komunikasi baik dengan tipe point-to-point maupun yang bersifat kolektif. Secara umum MPI memliki tujuan sebagai berikut :

1. MPI akan menjadi sebuah library untuk membangun program aplikasi dan bukan distributed operating system.

2. MPI akan mendukung thread-safe yang penting dalam symmetric multiprocessor pada lingkungan jaringan komputer yang heterogen.

3. MPI akan mampu untuk men-deliver high-performance computing.

4. MPI akan bersifat modular, untuk mengakselerasi development pustaka paralel yang portable.

5. MPI akan bersifat extensible, sehingga dapat terus dikembangkan dan memenuhi kebutuhan komputasi masa akan datang.

6. MPI akan mendukung heterogeneos komputasi.

7. MPI akan memiliki semantic behavior yang telah terspesifikasi dengan jelas, sehingga dapat menghindari beberapa permasalahan kritis seperti race-conditions, dead-lock dsb.

\section{Tipe Komunikasi MPI}

\section{- Point-to-Point Communication}

Pada implementasi program berbasis message-passing, point-to-point communication adalah komunikasi yang paling sederhana dimana akan melibatkan sepasang proses yang saling bekerjasama. Pada API dari MPI, secara sederhana dapat digunakan MPI_Send atau 
MPI_Recv, dimana akan mengizinkan terjadinya sebuah proses spesifik yang satu dapat mengirimkan data pesan ke sebuah proses spesifik yang lain.

Operasi point-to-point communication secara khusus berguna dalam komunikasi yang irregular ataupun yang berpola. Contoh: sebuah arsitektur data paralel dimana setiap prosessor secara rutin melakukan pertukaran region data dengan sebuah prosessor spesifik lainnya pada setiap langkah kalkulasi, atau pada arsitektur master-salve dimana sang master akan mengirim task data baru ke proses slave pada saat task data sebelummnya telah selesai.

\section{- CollectiveCommunication}

Berbeda dengan point-to-point communication, collective communication pada MPI API melibatkan komunikasi antara semua proses dalam sebuah group proses (dalam artian keseluruhan pool Proses atau sebuah subset terdefinisi pada program). Fungsi interface yang sederhana dapat berupa MPI_Bcast (broadcast) yang melakukan pengiriman data dari sebuah proses ke semua proses lainnya pada group, dan fungsi MPI_Reduce untuk melakukan kebalikannya.

Tipe komunikasi memberikan dua keuntungan, yaitu pertama, operasi komunikasi tersebut mengizinkan programmer untuk mengekspresikan operasi yang kompleks dengan menggunakan semantik yang sederhana, kedua, implementasi dapat melakukan pengoptimasian operasi melalui cara yang tidak disediakan oleh tipe operasi point-to-point communication.

\section{KESIMPULAN}

Dapat disimpulkan bahwa: pemetaan proses menggambarkan tata letak aktifitas yang terjadi dalam sebuah perusahaan. Menggunakan tools yang sesuai dapat berdampak baik pada perusahaan dan memperoleh keuntungan yang maksimal.

\section{SARAN}

Disarankan bahwa: pengguna dapat memilih salah satu tools pemetaan proses bisnis. Dikarenakan, setiap tools pemetaan proses bisnis memiliki keuntungan dan kelebihan tersendiri.

\section{DAFTAR RUJUKAN}

http://ccg.co.id/blog/2013/10/01/peta-proses-bisnis-dan-sop/ http://www.kumpulancontohmakalah.com/2017/01/Tipe.dan.Contoh.Perangkat.Lunak.Untuk. Pemetaan.Proses.Bisnis.html https://qualityengineering.wordpress.com/2008/06/30/pemetaan-proses/ https://sis.binus.ac.id/2014/04/30/diagram-swimlane/ http://www.intipesan.com/memahami-perbedaan-antara-kpi-dan-critical-success-factors-csf/ https://www.ketutrare.com/2013/04/mpi-message-passing-interface.html 